\title{
Could Enterprise Risk Management (ERM) Create, Protect and Enhance Shareholders' Wealth Among Malaysian Listed Issuers
}

\author{
Mohd Ariff Bin Kasim ${ }^{1 *}$, and Siti Rosmaini Binti Mohd Hanafi ${ }^{1}$ \\ ${ }^{1}$ Department of Accounting, College of Business Administration, Ajman University, 346, Ajman, \\ United Arab Emirates (UAE).
}

\begin{abstract}
The primary objective of this study is to explore the extent to which ERM implementation is capable of enhancing shareholders' wealth. A sample of 283 companies operating in the Main Market of Bursa Malaysia was selected. This study utilized the definition of ERM as the independent variable and shareholders' wealth as dependent variable. The overall observation revealed that ERM was significant in explaining the variation in shareholders' wealth. Objective setting, event identification, risk response, control activities, information and communication, and monitoring substantiated the hypothesized relationship. The research framework of this study, which utilized assumptions from stewardship and agency theory, could serve as guidance for future research on organizational control and governance. The study fills the gap in literature which mostly concentrated on the USA and western countries. The CRO and the board should focus more advising functions at the earlier stage of the ERM implementation and monitoring functions once ERM matured.
\end{abstract}

\section{Introduction}

In light of the rising incidence of corporate financial scandals, regulatory agencies around the world have struggled to focus on strengthening measures to prevent further corporate collapses arising from mismanagement or unexpected financial surprises. Analysts have suggested that ERM could offer a safety net against these types of unexpected surprises [1, 2]. The primary objective of ERM is to create, protect, and enhance shareholders' value by managing the uncertainties surrounding the achievement of the organization's objectives [3]. ERM could be one of the alternative governance tools to be deployed to protect companies from a wide range of exposures to risk [4].

Currently, the majority of studies on ERM have concentrated on the USA and western countries and little is known about ERM in other geographical locations, particularly Asia. This present study aims to bridge the gap in literature by empirically investigating ERM implementation in Malaysia. In its early stage, ERM implementation in Malaysia was mostly driven by consultants; thus, such implementation was lacking in empirical evidence. In this regard, the adoption of ERM in Malaysia could be attributable either to the influence of a general trend or alternatively to legislation imposing on firms an obligation to

*Corresponding author: m.ariff@ajman.ac.ae 
implement an ERM. Considering the fact that Malaysian listed issuers have started to invest in ERM, it is of paramount importance to shed light on the simple yet critical question that may be contemplated by stakeholders: does ERM implementation improve shareholders' wealth? Therefore, the primary objective of this study was to explore the extent to which ERM implementation is capable of enhancing shareholders' wealth, thus providing them with a reason for investment in ERM beyond mere fulfilment of the mandatory requirements imposed by Bursa Malaysia.

\section{Literature review}

The COSO suggested eight components of an integrated ERM framework: 1) internal environment, 2) objective setting, 3) event identification, 4) risk assessment, 5) risk response, 6) control activities, 7) information and communication, and 8) monitoring. The main criteria for evaluating the effectiveness of ERM is to measure the extent to which the eight components of the framework are executed. To date, studies providing empirical evidence of the impact of ERM implementation on financial performance are in their infancy [5-9]. The need for more research is critical considering the current tendency of regulatory authorities to shift their attention to ERM. Indeed, advocates of ERM have claimed that ERM is capable of enhancing shareholders' wealth; nevertheless, there have been mixed results surrounding this significant claim. Earlier ERM literature reported favorable impact of the ERM implementation such as those studies by [3, 5, 9-17].

It is interesting to note that ERM practice has evolved over the years and, since 2010, the focus has shifted from mere announcement of implementation of ERM to the appointment of a Chief Risk Officer (CRO) with responsibility for oversight and regulatory compliance. Studies $[18,19]$ found that the existence of the CRO related to reduction in the volatility of stock prices. The involvement of CRO was also reported to positively influence firm value [5]. It is possible that, over the years, ERM implementation has reached maturity, as recent studies have started to reveal more consistent sets of results on the impact of ERM on organizations. Study [20] suggested that firms demonstrated progressively higher value as the ERM matured. Further, study [21] suggested that the use of a dedicated risk manager is capable of improving the firm's operating performance and emphasized that the existence of a direct reporting line from the risk manager to the board or CEO could lead to superior firm value.

The fact that most of the existing studies concentrated on the USA and western countries obviously created a gap in the literature. Interesting, there are two studies from Malaysia that could shed light on ERM implementation in a different geographical setting. Studies $[22,23]$ generally discovered that ERM was not the main factor leading to value creation and that ERM implementation was not a significant variable in predicting variations in financial performance. This finding, in fact, contradicted all the previous studies, which reported a connection between ERM and shareholders' value. These empirical findings provide interesting grounds for further investigation as they are contrary both to the objective of ERM as highlighted by the COSO [24] and to various existing studies. These contradictory findings should not be ignored as the world was taken by surprise by the USA credit crisis which occurred in late 2008 and it is possible that the future will yield ever more shocking financial crises.

Remarkably, a recent study on ERM in China substantiated previous ERM studies in the USA and western countries. Study [25], involving 254 Chinese non-financial stateowned enterprises between 2006 and 2011, further confirmed the significance of ERM. They reported that ERM significantly increased firm value. More recent studies in ERM had incorporated corporate governance elements such as the board and senior executive management. Board was reported to be the most significance factor leading to an increase 
in senior management involvement in risk oversights [26]. Study [27] offers new insights in ERM literature by incorporating multi-theoretical approach utilizing a combination of institutional, agency resource dependency theory. Their study investigates maturity and board involvement in the ERM. It was reported that ERM matured firms tend to have more involvement from the board and senior management in the ERM monitoring task. The latest study [28] also incorporated various corporate governance attributes in an effort to understand ERM implementation among Italian private firms. They had incorporated six control variables, namely, profitability, leverage, firm dimension and complexity, quality of external audit, corporate ownership and industry characteristics. They concluded that ownership structure and size of the firm are capable of enhancing ERM implementation.

\section{Hypotheses development}

The implementation of ERM among Malaysian listed issuers is mandated by Bursa Malaysia's Practice Note 9 [29] and Listing Requirements, paragraph 15.26 (b) and such requirement therefore validates the control mechanisms highlighted in agency theory. There is apparent justification for the notion that agency theory may be an appropriate tool for theorizing on the impact of ERM implementation on firm value [30].

Study [8] suggested that the use of agency theory is likely to simplify the complexity inherent in real business environments. Indeed, further review of the individual attributes of the COSO's ERM framework revealed not only monitoring attributes but also advisory functions. In fact, seven out of the eight attributes of the ERM framework demanded a higher number of advisory than monitoring functions. Perhaps, the assumptions of stewardship theory provide a more satisfactory explanation of the advisory nature of the functions of the board and CRO in the context of successful implementation of ERM within an organization, particularly in the early stage of implementation. With reference to monitoring, the gap left by stewardship theory could be perfectly covered by the assumptions by agency theory that supports monitoring of overall ERM implementation.

Based on existing literature, this study identified five firms' specific attributes as control variables to overcome any undue influence on the ERM implementation. As the ERM is mandated for all listed companies in Malaysia, for the purpose of developing a comprehensive panoply of ERM tools, large firms may utilize greater financial resources than a small firm [27, 31-33]. Total revenue was used as proxy for firm size. The second and third control variables were the existence of a separate ERM unit and the existence of a CRO $[5,18,19,33]$. Small firms may not be able to afford a dedicated department focusing on ERM. Instead, these small firms may have just a Chief Audit Executive (CAE) to oversee this function. This is not the ideal concept for a perfect ERM environment. At the other end, firms with a dedicated and well-structured ERM unit are often led by a CRO. The fourth control variable was the duration of the ERM implementation as a proxy for ERM maturity. Despite the mandatory requirement for ERM, not all listed firms had the same maturity or degree of ERM implementation. At the initial stage, firms may allocate most resources to educating staff and creating awareness of the ERM than on the design of an appropriate ERM framework. At the later stage, the focus inevitably shifts to the implementation of the ERM. Studies have revealed that mature firms demonstrate superior ERM implementation then less mature companies [27, 31, 32]. Finally, firms in different industries may be subject to different types and frequencies of risk; the varying level of risk thus served as one of the control variables. Generally, banking and financial institutions would be more exposed to various risks and would be more likely to have a more comprehensive ERM system. Existing literature reported that the degree of the ERM implementation is affected by industry classification [27, 28, 34, 35]. It is hypothesized that, upon controlling for the effect of the above control variables, significant relationships 
would exist between ERM implementation and shareholders' wealth, as measured by firm value $[5,6,12]$, earnings before interest, taxes, depreciation and amortization (EBITDA) $[13,14]$, and ROE [14]. The equation below depicts the hypothesized relationships. Figure 1 summarizes the expected relationships between ERM implementation and shareholders' wealth.

$$
\begin{gathered}
\mathrm{Y}=\alpha 0+\gamma 1 \mathrm{Xc} 1+\gamma 2 \mathrm{Xc} 2+\gamma 3 \mathrm{Xc} 3+\gamma 4 \mathrm{Xc} 4+\gamma 5 \mathrm{Xc} 5+\beta 1 \mathrm{X} 1+\beta 2 \mathrm{X} 2+\beta 3 \mathrm{X} 3+\beta 4 \mathrm{X} 4+\beta 5 \mathrm{X} 5 \\
+\beta 6 \mathrm{X} 6+\beta 7 \mathrm{X} 7+\beta 8 \mathrm{X} 8+\epsilon
\end{gathered}
$$

where $\mathrm{Y}=$ Shareholders' Wealth (Proxy: Firm Value, EBITDA and ROE)

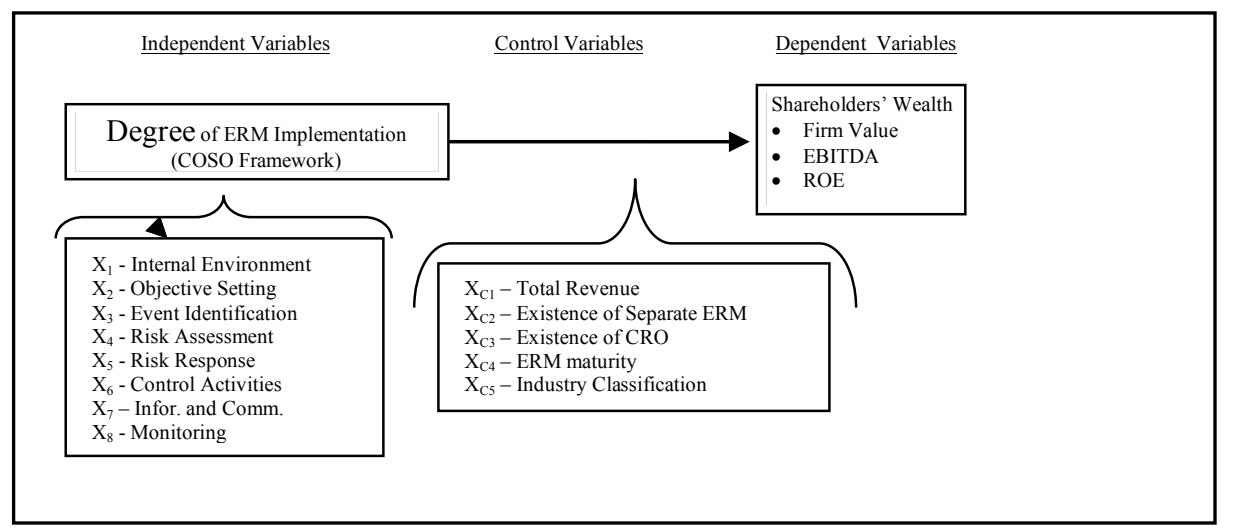

Fig. 1. Expected relationships between ERM implementation and shareholders' wealth

\section{Methodology}

The study utilized the definition of ERM and the framework proposed by the COSO [24] as the independent variable. A self-reported instrument was used to measure the degree of ERM implementation. The instrument was adopted from [23]. The instrument also used unique measurement scales that enabled ratio data to be collected (as such data measure the degree of implementation or compliance with the COSO ERM framework). There were 823 listed companies on Bursa Malaysia. Ideally a sample size of 263 companies should be sufficient for a satisfactory sample size. Considering the possibility of a lower response rate, a total of 823 copies of the questionnaires were distributed by mail to all the companies in the population. A copy with return paid envelope was mailed to the CRO for companies that had a Risk Management department/ unit; otherwise it was mailed to the CAE heading the Internal Audit department. The data collection procedure took place from December 17, 2014 to June 30, 2015. Significant efforts were devoted to ensuring the highest response rate via multiple emails and text messages. Eventually, 306 copies of the questionnaires were returned of which 23 copies were blank. A total of 269 copies were returned within the data collection period while another 14 surveys were received in July 2015. Finally, the total number of respondent companies was 283. With regard to the dependent variable, firm value, EBITDA and ROE were the proxies used as a basis for measuring shareholders' wealth were obtained from the Osiris database between July 1, 2015 and July 31, 2015. The data were extracted from the latest available financial data, mostly for the year ended December 31, 2014. 
Table 1: Descriptive Statistics

\begin{tabular}{llcc}
\hline \multicolumn{1}{c}{ Variables } & Definition & Frequency & Percent \\
\hline & Banking, insurance and financial & 118 & 41.7 \\
& institution & & \\
& Plantation & 17 & 6.0 \\
Industry class & Construction & 32 & 11.3 \\
& Trading & 60 & 21.2 \\
& Automotive & 56 & 19.8 \\
\hline & $\begin{array}{l}\text { in the first year of the ERM } \\
\text { implementation }\end{array}$ & 24 & 8.5 \\
& $\begin{array}{l}\text { in the 2-3 years of the ERM } \\
\text { implementation }\end{array}$ & 167 & 59.0 \\
ERM maturity (Duration of the & & 40 & 14.1 \\
ERM) & $\begin{array}{l}\text { in the 4-5 years of the ERM } \\
\text { implementation }\end{array}$ & 52 & 18.4 \\
& beyond fifth years of ERM & & \\
\hline \multirow{2}{*}{ implementation } & 230 & 81.3 \\
\hline \multirow{2}{*}{ Existence of CRO } & separate ERM unit/ Department & 53 & 18.7 \\
\hline
\end{tabular}

\section{Results}

Table 1 depicts the respondents' demographic information coupled with descriptive statistics of relevant variables. All variables that were subject to multiple regressions were transformed using Inverse Distribution Function method. Factor analysis was performed, the results of which are presented in Table 2. There were eight components extracted (Varimax with Kaiser Normalization, suppressed at 0.50) and factor scores from each were used to test the hypothesized relationships. Each factor was then named accordingly. Factor 1 was termed Monitoring, Factor 2-Event Identification, Factor 3-Information and Communication, Factor 4-Objective Setting, Factor 5-Risk Response, Factor 6Risk Assessment, Factor 7-Control Activities and Factor 8-Internal Environment. The factors were then rearranged to reflect the sequence in the COSO ERM framework.

Panel A: KMO and Bartlett's Test

Table 2. Factor Analysis

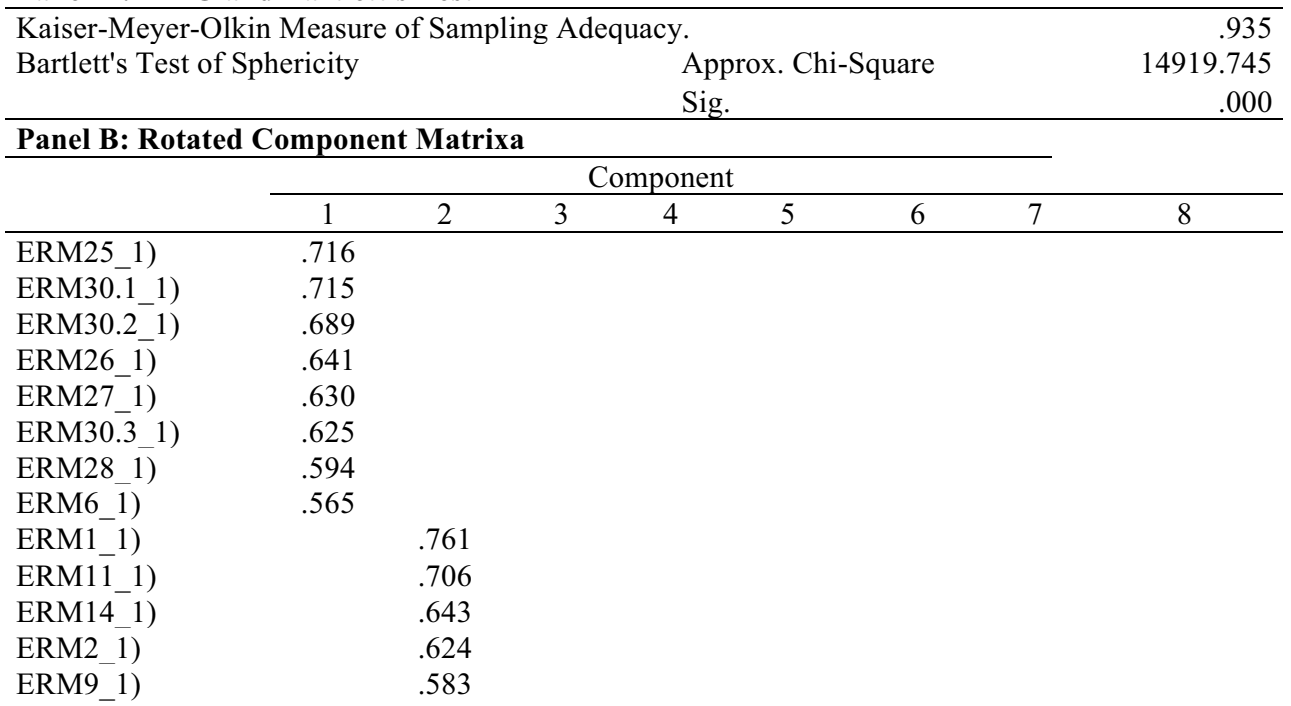




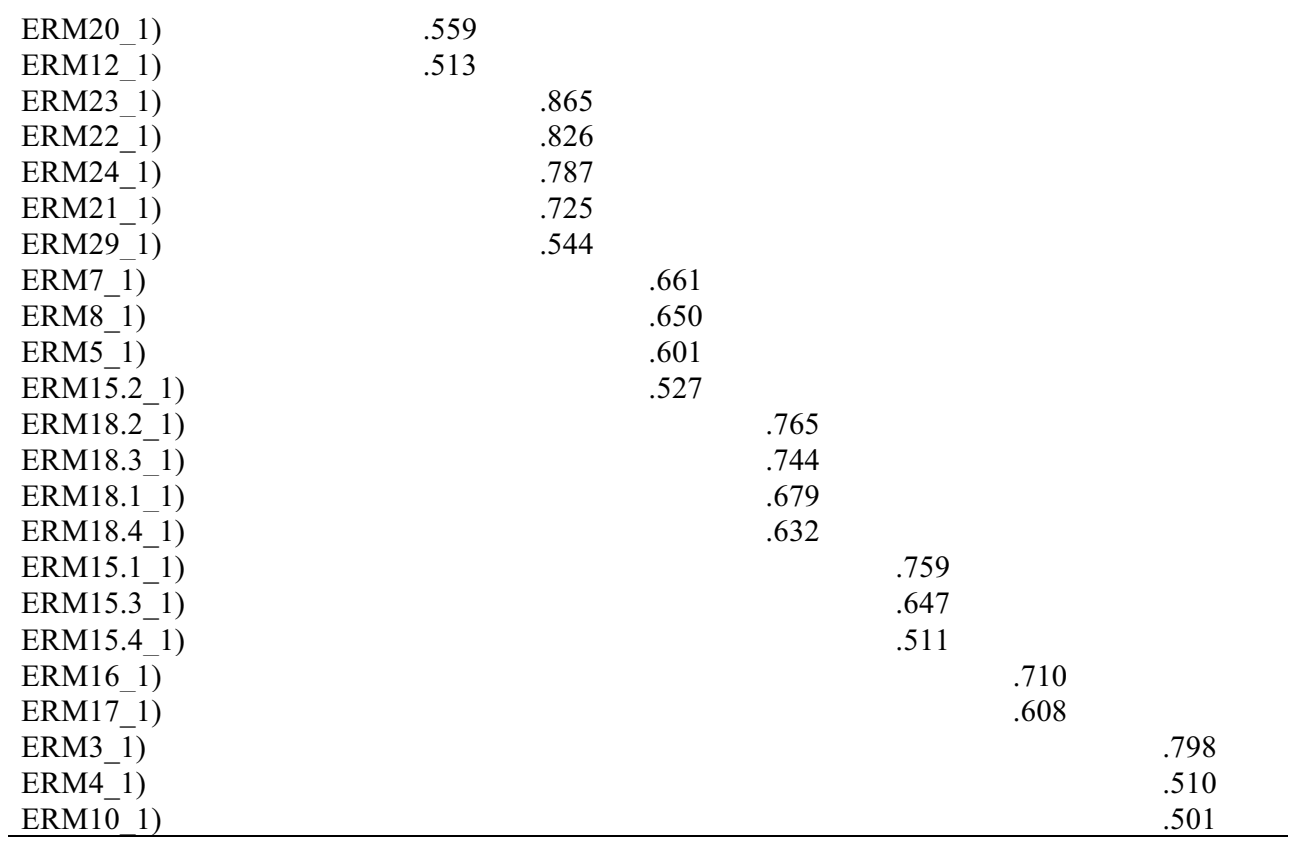

Table 3 depicts the results of the hierarchical multiple regressions on the hypothesized relationships. Multiple analyses were performed to substitute different measures or proxies for shareholders' wealth. There were five control variables in the analyses - 1) Total Revenue, 2) existence of separate ERM unit, 3) Existence of CRO, 4) ERM maturity, and 5) Industry Classification. The overall observation revealed that ERM was significant in explaining the variation in shareholders' wealth. With reference to firm value, X2 Objective Setting (coeff. 881.576, p-value 0.045), X3- Event Identification (coeff. 95.947, p-value 0.040), X5 - Risk Response (coeff. 1013.621, p-value 0.026), X6 Control Activities (coeff. 944.610, p-value 0.037) and X7- Information and Communication (coeff. 1128.478, p-value 0.014) were among the ERM variables that reported significant direct/ positive relationships with firm value. It is significant that, after controlling for the effect of five variables, all ERM variables reported positive relationships with firm value, thus supporting the hypothesized relationship that ERM implementation leads to better firm value. The second proxy utilized, EBITDA, revealed an interesting pattern of results. X1 - Internal Environment and X2 - Objective Setting reported negative relationships with EBITDA. All other ERM variables ( X3-Event Identification, X4 - Risk Assessment, X5 - Risk Response, X6 - Control Activities, X7 - Information and Communication and X8 - Monitoring) revealed positive relationships with EBITDA, though not at 0.05 levels of significance. The third measure of shareholders' value, ROE, revealed four ERM variables reported significant relationships with ROE. X3 - Event Identification (coeff. 0.409, p-value 0.003), X5 - Risk Response (coeff. 0.093, p-value 0.032), X7 - Information and Communication (coeff. 0.204, pvalue 0.047 ) and X8 - Monitoring (coeff. 0.397, p-value 0.002). All other ERM variables reported mixed (positive and negative) relationships with ROE but not at 0.05 significance levels.

The unique insignificance pattern of results for EBITDA certainly raised some concern. Most probably, this is due to the fact that majority (59 percent) of the respondent were in the 2-3 years period of the ERM implementation which reflect their ERM's maturity. Perhaps the intended impact of the ERM on the primary business 
operations is yet to be visualized. Interestingly, ERM seems to have a favorable impact on firm value and ROE. Two control variables reported a consistent pattern of results throughout the three regression analyses. XC1 - Total Revenue and XC5 - Industry Classification revealed to be significant variables capable of influencing the overall relationship between ERM variables and shareholders' wealth.

Table 3: Impact of ERM implementation on shareholders' wealth

\begin{tabular}{|c|c|c|c|c|c|c|c|c|c|}
\hline \multirow{2}{*}{$\frac{\text { Type of Observations }}{\text { Variables }}$} & \multicolumn{3}{|c|}{ Firm Value } & \multicolumn{3}{|c|}{ EBITDA } & \multicolumn{3}{|c|}{ ROE } \\
\hline & Coef. & p-value & VIF & Coef. & p-value & VIF & Coef. & p-value & VIF \\
\hline$\overline{\text { Constant }}$ & 3055.083 & .252 & & 141.853 & .690 & & 1.961 & $.010^{*}$ & \\
\hline XC1 - Total Revenue & 1.397 & $.000 *$ & 1.702 & .121 & $.000 *$ & 1.702 & .000 & $.000 *$ & 1.737 \\
\hline XC2 - Separate ERM unit & 1079.168 & .437 & 1.657 & 137.428 & .457 & 1.657 & -.514 & .214 & 1.826 \\
\hline $\mathrm{XC} 3$ - Existence of CRO & 1173.936 & .401 & 1.823 & 162.210 & .384 & 1.823 & .160 & .696 & 1.897 \\
\hline XC4-ERM maturity & -623.284 & .254 & 1.206 & 4.298 & .953 & 1.206 & -.090 & .590 & 1.532 \\
\hline XC5 - Industry Class. & -913.455 & $.010^{*}$ & 1.871 & -127.441 & $.007 *$ & 1.871 & -.409 & $.000 *$ & 1.861 \\
\hline X1 - Internal Environment & -7.770 & .986 & 1.034 & -3.226 & .956 & 1.034 & .080 & .533 & 1.090 \\
\hline X2 - Objective Setting & 881.576 & $.045^{*}$ & 1.082 & -42.898 & .463 & 1.082 & .168 & .188 & 1.112 \\
\hline X3 - Event Identification & 95.947 & $.040^{*}$ & 1.203 & 22.278 & .724 & 1.203 & .409 & $.003 *$ & 1.185 \\
\hline X4 - Risk Assessment & 240.428 & .601 & 1.145 & 70.267 & .252 & 1.145 & -.074 & .577 & 1.141 \\
\hline X5 - Risk Response & 1013.621 & $.026^{*}$ & 1.126 & 38.443 & .526 & 1.126 & .093 & $.032 *$ & 1.130 \\
\hline X6 - Control Activities & 944.610 & $.037 *$ & 1.133 & 61.523 & .306 & 1.133 & -.140 & .273 & 1.111 \\
\hline $\begin{array}{l}\text { X7 - Information and } \\
\text { Comm. }\end{array}$ & 1128.478 & $.014^{*}$ & 1.139 & 34.133 & .576 & 1.139 & .204 & $.047 *$ & 1.304 \\
\hline X8 - Monitoring & 369.798 & .412 & 1.102 & 2.236 & .970 & 1.102 & .397 & $.002 *$ & 1.118 \\
\hline$\overline{\mathrm{R}}$ & & & .700 & & & .528 & & & .754 \\
\hline $\mathrm{R}^{2}$ & & & .490 & & & .279 & & & .568 \\
\hline Adj. $\mathrm{R}^{2}$ & & & .465 & & & .244 & & & .547 \\
\hline Std. Error of the estimate & & 703 & 6.53136 & & & 7.77712 & & & 1.98414 \\
\hline $\mathrm{R}^{2}$ change & & & .038 & & & .010 & & & .043 \\
\hline F change & & & 2.495 & & & .468 & & & 3.288 \\
\hline Sig. F change & & & .013 & & & .878 & & & .001 \\
\hline$F$ value & & & 19.741 & & & 7.934 & & & 26.532 \\
\hline p-value & & & .000 & & & .000 & & & .000 \\
\hline
\end{tabular}

\section{Discussion, conclusion and managerial implications}

The present results justified the dual-theoretical approach that combines stewardship and agency to theorize the relationships between the advising and control functions exercised by the CRO and board. One may argue that ERM itself is part of a set of external control mechanisms as it is mandated by regulatory agencies. Nevertheless, the implementation of ERM within an organization involves a combination of both advising and control functions. Evidently, overall results supported the hypothesized relationships and further substantiated recent studies on the significance of ERM in enhancing shareholders' wealth [25, 27, 28, 31-33]. Specifically, the following ERM attributes reported significant positive impacts on shareholder's wealth-objective setting, event identification, risk response, control activities, information and communication and monitoring. Though this study was conducted in a similar research setting to two earlier studies on ERM in Malaysia [22, 23], the present results interestingly failed to substantiate the findings of those two studies, particularly the fact that ERM did not have a significant influence on shareholders' wealth.

Up until now, ERM literature concentrated on US and western countries; this study enriches the literature by offering fresh insights in different geographical settings. This study both provided much-needed empirical input concerning the extent and nature of ERM implementation and identified the theoretical foundation underlying ERM as a governance tool. Indeed, the implementation of ERM is capable of enhancing shareholders' wealth. 
The present study also substantiated the notion that the primary objective of ERM is to create, protect, and enhance shareholders' wealth. It is hoped that the results of this study will enrich the current ERM literature. The results support the validity of a dual-theoretical construct based on stewardship and agency to theorize the dynamic interrelations between firms' advising and control functions. It is anticipated that this study will shed light on and promote additional empirical studies to further test both its hypothesized relationships and its theoretical justifications. The results rationalized the mandatory requirements imposed by Bursa Malaysia [29] concerning the implementation of ERM. This study is among the very few empirical studies that utilized the COSO's ERM framework to assess the degree of ERM implementation. Nonetheless, it was measured using self-reported questionnaires and hence is affected by various limitations commonly found in studies using self-reported instruments. The study relied solely on self-reported responses and failed to corroborate the results with alternative measures. Future studies may fruitfully explore alternative approaches to self-reported measures - such as those in studies [5, 9, 31], while at the same time retaining a similar theoretical foundation.

This study chose to view ERM implementation as part of the firm's advising and control functions based on stewardship and agency theory; thus, the board and CRO are assumed to be the primary entities responsible for the success of ERM implementation. Further, the CRO could lobby the board and CEO to incorporate elements of ERM into staff performance appraisals, thus indirectly forcing the staff to embrace the ERM philosophy in their daily business operations. A continuous education program across various units in the organization is an indispensable element of an ERM strategy. Ultimately, once the ERM philosophy has pervaded the organization's daily routine, the $\mathrm{CRO}$ and the board will be able to visualize not only a significant improvement in business operations, but also an increase in shareholders' wealth.

\section{Note:}

The ERM instrument utilized in this study is available upon request. Kindly contact the corresponding author: m.ariff@ajman.ac.ae

\section{References}

1 Ye, Y.G., Liu, N., and Cao, R.X.: 'Risk Analysis for Listed Insurance Companies in China: Based on Contingent Claim Approach', in Editor (Ed.)^(Eds.): 'Book Risk Analysis for Listed Insurance Companies in China: Based on Contingent Claim Approach' (2008, edn.), pp. 12-19

2 Culp, C.L., and O'Donnell, K.J.: 'Catastrophe reinsurance and risk capital in the wake of the credit crisis', The Journal of Risk Finance, 2009, 10, (5), pp. 430 - 459

3 Walker, P.L., Shenkir, W.G., and Barton, T.L.: 'Enterprise Risk Management: Pulling it All Together' (The Institute of Internal Auditors Research Foundation (IIARF), 2002. 2002)

4 Burnaby, P., and Hass, S.: 'Ten steps to enterprise-wide risk management', Corporate Governance, 2009, 9, (5), pp. 539-550

5 Hoyt, R.E., and Liebenberg, A.P.: 'The Value of Enterprise Risk Management', Journal of Risk and Insurance, 2011, 78, (4), pp. 795-822

6 McShane, M.K., Nair, A., and Rustambekov, E.: 'Does enterprise risk management increase firm value?', Journal of Accounting, Auditing \& Finance, 2011, 26, (4), pp. 641-658 
7 Sarens, G.: 'Internal Auditing Research: Where are we going? Editorial', International Journal of Auditing, 2009, 13, (1), pp. 1-7

8 Bromiley, P., McShane, M., Nair, A., and Rustambekov, E.: 'Enterprise risk management: Review, critique, and research directions', Long range planning, 2015, 48, (4), pp. 265-276

9 Gordon, L.A., Loeb, M.P., and Tseng, C.-Y.: 'Enterprise risk management and firm performance: A contingency perspective', Journal of Accounting and Public Policy, 2009, 28, (4), pp. 301-327

10 Cassidy, S.M., Constand, R.L., and Corbett, R.B.: 'The market value of the corporate risk management function', Journal of risk and insurance, 1990, pp. 664-670

11 Smith, C.W.: 'Corporate risk management: theory and practice', Journal of Derivatives, 1995, 2, (4), pp. 4-12

12 Sinclair, S.: 'Essays in multiperiod risk management with information updating'. Ph.D., University of Pennsylvania, 2004

13 Ertugrul, M.: 'Essays on agency problems and corporate governance'. Ph.D., The University of Connecticut, 2005

14 Lin, Wu, S., Penm, J.H.W., and Terrell, R.D.: 'The relationship and causality testing between diversification, risk and financial performance: Empirical examination in Taiwan's banking industry', International Journal of Services, Technology and Management, 2005, 6, (6), pp. 556-574

15 Simkins, B.: 'Enterprise Risk Management: Current Initiatives and Issues Journal of Applied Finance Roundtable', Journal of Applied Finance, 2008, 18, (1), pp. 115-132

16 Andersen, T.J.: 'The performance relationship of effective risk management: Exploring the firm-specific investment rationale', Long Range Planning, 2008, 41, (2), pp. 155176

17 Andersen, T.J.: 'Effective risk management outcomes: exploring effects of innovation and capital structure', Journal of Strategy and Management, 2009, 2, (4), pp. 353-379

18 Pagach, D., and Warr, R.: 'The characteristics of firms that hire chief risk officers', Journal of Risk and Insurance, 2011, 78, (1), pp. 185-211

19 Pagach, D.P., and Warr, R.S.: 'The effects of enterprise risk management on firm performance', Available at SSRN 1155218, 2010

20 Farrell, M., and Gallagher, R.: 'The Valuation Implications of Enterprise Risk Management Maturity ', Journal of Risk and Insurance, 2015, 82, (3), pp. 625-657

21 Grace, M.F., Leverty, J.T., Phillips, R.D., and Shimpi, P.: 'The Value of Investing in Enterprise Risk Management ', Journal of Risk and Insurance, 2015, 82, (2), pp. 289316

22 Manab, N.A.: 'Enterprise-wide risk management (EWRM) implementation, compliance and value creation among public listed companies (PLCs) in Malaysia'. Ph.D, Universiti Teknologi MARA, 2009

23 Kasim, M.A., Aziz, A.A., and Kassim, I.: 'Enterprise Risk Management (ERM) in Malaysia: A Study of the Status of Implementation, the Role of Internal Audit and the Impact on Organisational Performance' (LAP LAMBERT Academic Publishing, 2011. 2011)

24 COSO: 'Enterprise Risk Management- Integrated Framework-Executive Summary' (The Committee of Sponsoring Organisations of the Treadway Commission 2004. 2004)

25 Ai, J., and Chen, H.: 'Does ERM Improve Firm Value? Evidence from Listed Chinese Nonfinancial SOEs', Evidence from Listed Chinese Nonfinancial SOEs (December 15, 2014), 2014

26 Beasley, M., Branson, B., and Hancock, B.: 'Current state of enterprise risk oversight: Progress is occurring but opportunities for improvement remain’, in Editor (Ed.)^(Eds.): 
'Book Current state of enterprise risk oversight: Progress is occurring but opportunities for improvement remain' (2012, edn.), pp.

27 Beasley, M., Branson, B., and Pagach, D.: 'An analysis of the maturity and strategic impact of investments in ERM', Journal of Accounting and Public Policy, 2015, 34, (3), pp. 219-243

28 Mafrolla, E., Matozza, F., and D'Amico, E.: 'Enterprise Risk Management In Private Firms: Does Ownership Structure Matter?', Journal of Applied Business Research, 2016, 32, (2), pp. 671

29 Bursa Malaysia: 'Practice Note 9: Internal Control and Corporate Governance Statement', in Editor (Ed.)^(Eds.): 'Book Practice Note 9: Internal Control and Corporate Governance Statement' (Bursa Malaysia Securities Berhad, 2012, edn.), pp.

30 Jerry, A.M., Hively, K., and Merkley, B.W.: 'Enterprise Risk Management: Trends and Emerging Practices' (IIA Research Foundation, 2001. 2001)

31 McShane, M.K., Nair, A., and Rustambekov, E.: 'Does Enterprise Risk Management Increase Firm Value?', 2011, 26, (4), pp. 641-658

32 Farrell, M., and Gallagher, R.: 'The valuation implications of enterprise risk management maturity', Journal of Risk and Insurance, 2015, 82, (3), pp. 625-657

33 Grace, M.F., Leverty, J.T., Phillips, R.D., and Shimpi, P.: 'The value of investing in enterprise risk management', Journal of Risk and Insurance, 2015, 82, (2), pp. 289-316

34 Beasley, M.S., Clune, R., and Hermanson, D.R.: 'Enterprise risk management: An empirical analysis of factors associated with the extent of implementation', Journal of Accounting and Public Policy, 2005, 24, (6), pp. 521-531

35 Beasley, M., Pagach, D., and Warr, R.: 'Information conveyed in hiring announcements of senior executives overseeing enterprise-wide risk management processes', Journal of Accounting, Auditing \& Finance, 2008, 23, (3), pp. 311-332 